\title{
A DAY IN THE LIFE OF A MEDICAL OFFICER
}

\author{
A Whitton, General Practitioner \\ Lancaster
}

Having been a member of the Territorial Army for several years, I was mobilised to serve in Iraq in October 2003. I spent three months as part of Operation Telic 3, the British Army's contribution to the multi-national force. For the majority of the time I was located in Al Amarah. I hope that this article can give the reader an impression, from a personal viewpoint, of daily life in post-conflict Iraq as an army doctor.

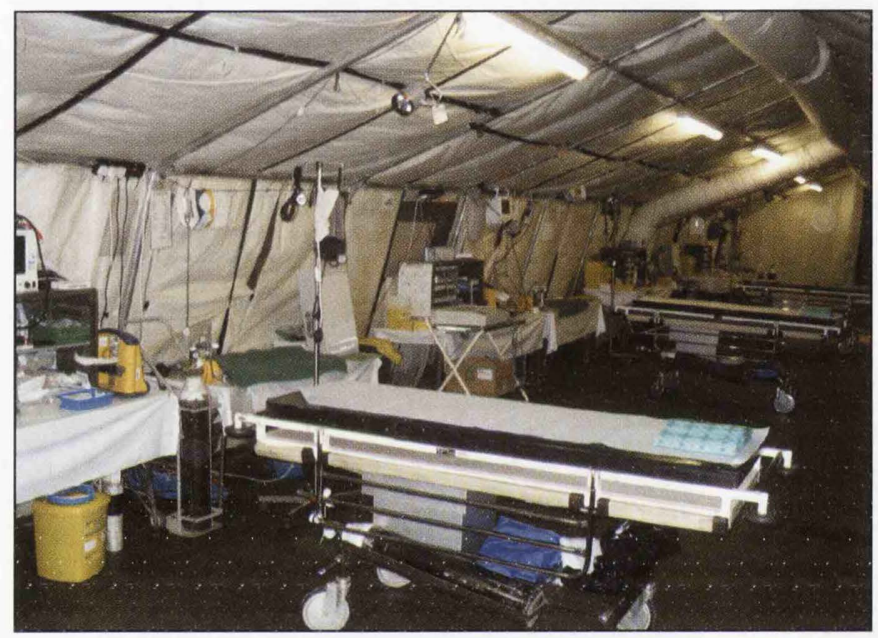

A\&E Department at the British Military Hospital

\section{ABU NAJI CAMP, AL AMARAH, MAYSAN PROVINCE, IRAQ}

Abu Naji camp is located $5 \mathrm{~km}$ south of $\mathrm{Al}$ Amarah, the provincial capital of Maysan Province in Iraq. Al Amarah is situated on the right bank of the river Tigris astride route 6 . The town is about halfway between Basra and Baghdad, having a population of around 300,000 . The Iranian border is $60 \mathrm{~km}$ to the east. The surrounding area is open, flat and featureless. The marshlands and flood plain of the Tigris River lie about $20 \mathrm{~km}$ to the southeast.

\section{Daybreak}

The day usually starts as dawn is breaking around 06.30 . Buglers of 1st Battalion The Light Infantry awake the camp with reveille. The place begins to come alive with breakfast, starting at 0700 for the majority of the 1,200 soldiers. Mornings are cold at this time of the year. The temperature does not warm up until about midday. There have been frequent rainstorms with local flooding and the nights are invariably cold. Co-located with the military are civilians who are assisting the Iraqi administration in restoring their country. These government-sponsored personnel are responsible for the budgets for health, policing, security and repairing the infrastructure of Iraq.
Breakfast offers a choice of continental or the traditional cooked option. Served as a buffet in the tented cookhouses by the army chefs, it consists of produce shipped from the UK or other gulf states. Nothing is sourced locally due to security risks.

\section{Morning routine}

Following breakfast, on a typical morning, I walk the short distance to the ward. This is run by three shifts of RGNs and CMTs (Combat Medical Technicians) who look after the 13 beds. Three of these are dedicated to infectious diseases. There is an expansion capability of another 20 beds in a nearby tented facility. I usually attend the ward first in order to review the patients, some of whom have been admitted during the previous evening with the diarrhoeal infection that has been sweeping through camp. It is the third such minor epidemic during my tour. The illness is characterised by a sudden increase in temperature, abdominal cramps and profuse watery stools, with or without vomiting. Our management has been bed rest in a controlled environment to segregate the infected, and hopefully limit the spread of the symptoms. Infection tends to spreads rapidly as the troops are accommodated in blocks of 10 -men rooms. Consequently it is not unusual for the inhabitants of a room to rotate through the ward in turn.

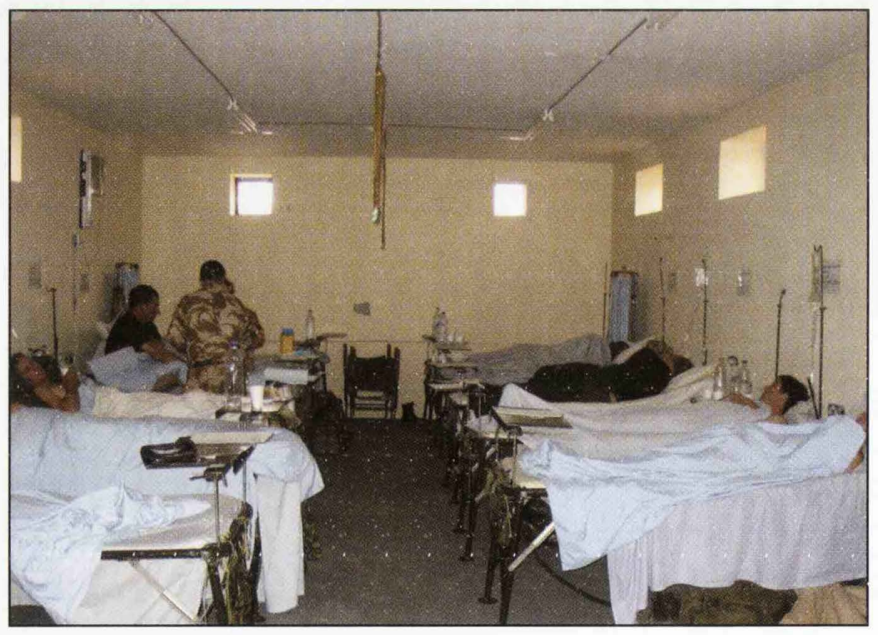

Ward at Al Amarah during D\&V epidemic

Investigational facilities at Abu Naji are extremely limited. Any pathological specimen requires a helicopter flight to the British Military Hospital at Shaibah in the south of Iraq. The results are received within a week, if we are lucky. Consequently we do not routinely monitor stool samples, except for those from people concerned with food handling or anyone with worrying symptoms. In previous outbreaks the samples cultured have not grown pathogens. It has been assumed therefore that the main causative organism is a rotavirus or norwalk virus. However of late the stool 
specimens have been returned containing the shigella species. This has meant that we have had to redouble our efforts at improving hygiene within the camp to prevent further spread.

Fortunately, today, the seven patients are all well and I am able to discharge three of them back to duties. As the duties may include standing guard in isolated sangers or manning observation posts for up to three days it is important that the soldiers are fit and well. The soldiers' duties are very varied and may involve foot patrols, vehicle check points, guarding of power lines, supporting the local police, weapon searches, observation of the nearby Iranian border and training of the newly formed Iraqi Civil Defence Corps.

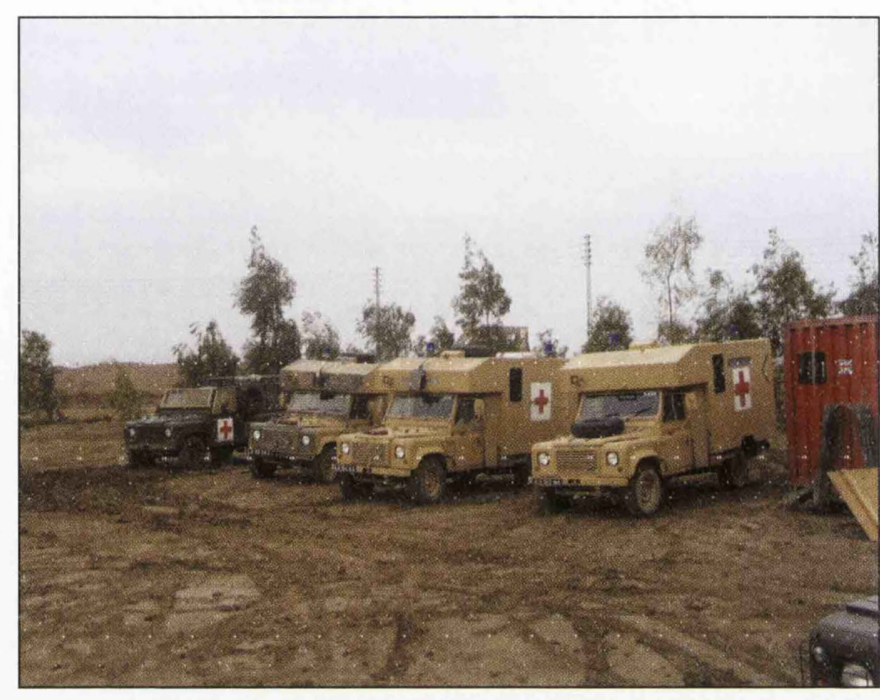

Ambulance station

After the ward round I go to the A\&E department, located in a corner of the camp. I meet with my RGN counterpart who also happens to be from the Territorial Army. His normal place of work is the Regional Burns ITU at Wythenshawe Hospital in Manchester. We discuss the morning's training programme, which has been arranged for the CMTs. This starts at 0900 with a series of trauma moulages, and is usually followed by a small triage exercise. The CMTs are trained to be equivalent to NHS ambulance technicians, but tend to lack practical hands-on experience. The emphasis of our training is on pre-hospital medical care within a battlefield scenario.

My duties involve working a 24-hour on/off shift. The A\&E facility has two resuscitation bays and a minor treatment area. It is well equipped, being deemed sufficient to deal with two seriously injured casualties in the event of a major incident. The population at risk is around 2000, which includes the military, civilian contractors, locally employed contractors (known colloquially as Chogis) and the staff of a variety of other organisations which provide support to the Iraqi Civilian Administration.

At 10.00 I attend the daily orders group given by the troop commander. She has already attended the battlegroup orders group and disseminates the information from this to her medical command of 45 personnel. The information is a mixture of administrative matters and a summary of the current intelligence situation in Iraq, including any ongoing operations or contacts that have occurred within the preceding 24 hours. The meeting gives me the opportunity to meet the other medical personnel, including the camp dental officer.

The rest of the morning is taken up with a variety of tasks. These may be mundane such as doing my washing, having my hair cut, or reading, all usually interrupted by a steady influx of patients. The patients suffer the usual mix of conditions seen in primary care. However, the majority of the practice population are young and fit, therefore there are no chronic disease issues. Most of the illness is either infective or the result of minor trauma. Troops are frequently deployed for days at a time, and on return to camp often require medical attention to patch up injuries. Work therefore tends to be episodic and is always reactive to operational commitments. There is no appointment system, the patients being seen immediately. The records are hand written, based on patient-held documentation. A military version of the EMIS system is used in theatre, but is not networked to the mainframe in the UK

\section{Midday}

Lunch runs from 12.00-13.30, and like all meals is a focus for the day. Mealtimes are an opportunity to meet colleagues and other members of the battlegroup. Like most of the meals there is a choice of main courses, including a nutritious but repetitive salad bar at lunchtime. All utensils and plates are plastic as washing facilities are limited. Hand-washing is strictly enforced before meals to reduce the risk of infection. Waste is constantly destroyed during the day in burn pits.

During lunchtime our serenity was disturbed by the sound of discharging shotguns. 'Mutt Patrol' was out in force today. Feral dogs frequently stray into camp; however, the rabies risk precludes their attraction as pets.

\section{An emergency call}

Today's afternoon involved an emergency call from the south of Maysan Province near the town of Al Majarr Al Kabir. One of the patrols of the Light Infantry had come under fire from feuding tribesmen. Casualties had been sustained. (I only found out later that this was the town in which six military policemen were killed last year). This was the scenario given to me as the IRT (Immediate Reaction Team) commander. There were no details of casualty numbers or whether they were British or Iraqi personnel.

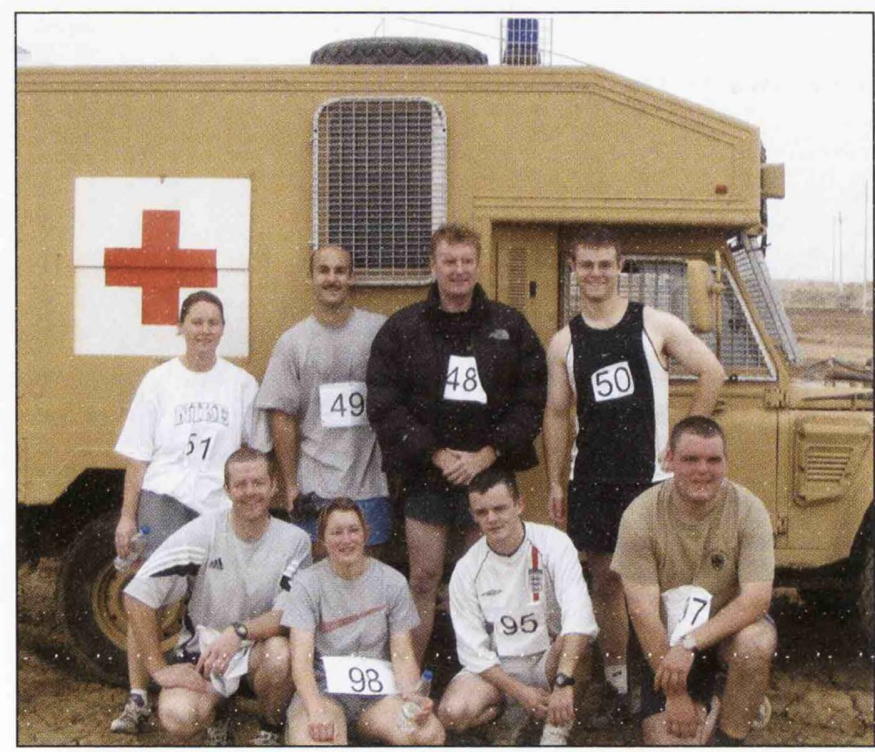

The Maysan half-marathon

The IRT is on constant readiness at Al Amarah where it is deployed by RAF Chinook helicopter. On this occasion we were accompanied by a section of 10 soldiers from the 9/12th Lancers who were to provide our medical team with defensive protection. The Chinook took off whilst we went through our mental preparations. not helped by the erratic 
low flying that is required in these parts to avoid potential missile threats. The tail and side gunners remain on constant vigilance against a possible ground attack from rocketpropelled grenades or anti-aircraft missiles and continue to sweep the area with their 50-calibre machine guns during the 20-minute flight.

The Chinook circled the landing area and we were off the tailgate at a run. Ahead was an Iraqi village and a huge crowd of locals, about 100 metres in the distance. A few pickup trucks were also visible; it resembled a scene out of 'Blackhawk Down'. There is nothing attractive about Iraqi villages, which are usually densely packed conglomerations of mud-brick houses crowded with inhabitants. Malodorous sluggish streams surround the villages where irrigation ditches double as sewers. Reed beds and the occasional date palm garden complete the scene. I met with the ground commander who told me that his troops had returned fire after having become embroiled in a fire-fight with two groups of locals. They had hit 7 Iraqis, killing one instantly; the others had already been evacuated to the hospital in the town. Having no-one to treat, we re-embarked and flew back to camp.

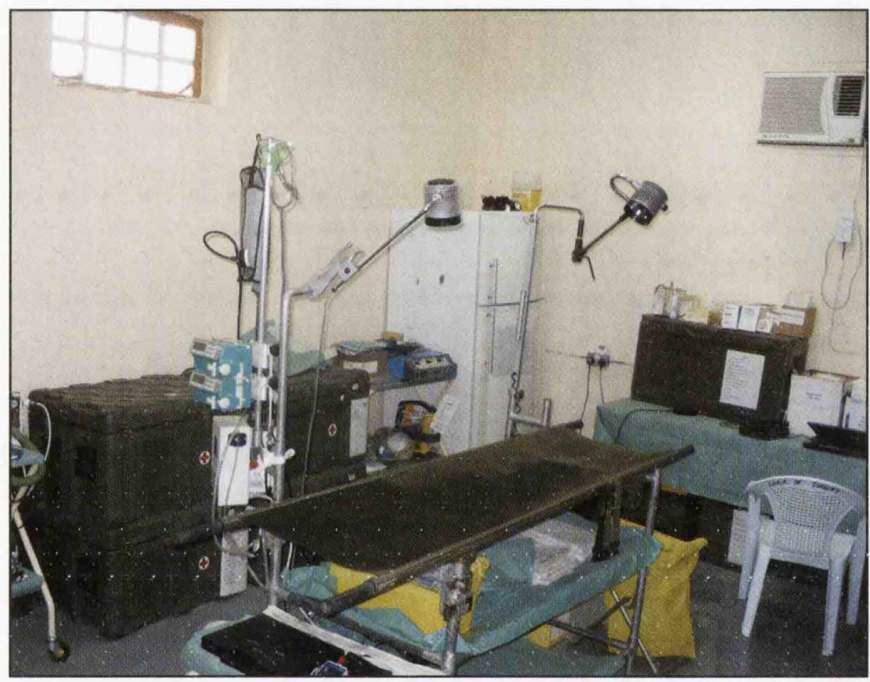

Damage control surgical facility

Previous calls with the IRT have been to casualties of gunshot wounds from both Coalition personnel and Iraqi people, and road traffic accidents. On one occasion we were deployed by winch to a minefield strike when a local man inadvertently blew himself up. He had been trying to hammer off the copper casing of a discarded artillery shell in the middle of a marked minefield. The recycling of copper and aluminium is very lucrative for the local economy. The ingots made from the recycled munitions or powerlines are then sold on to the Iranians.

\section{Afternoon routine}

The IRT call completed, we returned to the A\&E department. The medics had been deployed in our absence to cover the thrice-weekly arrival of the Hercules transport aircraft, which provides us with supplies and, more importantly, post. This flight is the camp's lifeline. A worry for the pilots is that they have had a number of 'lock-ons' from surface-to-air missiles and so in the past have had to deploy their aerial counter measures.

I normally go for a run around camp by 17.00 hours, before it gets too dark. The circuit is monotonous, being 1.7 miles, both clockwise and anti-clockwise. An alternative is the tented gym offering a selection of freestanding weights or $\mathrm{CV}$ machines.

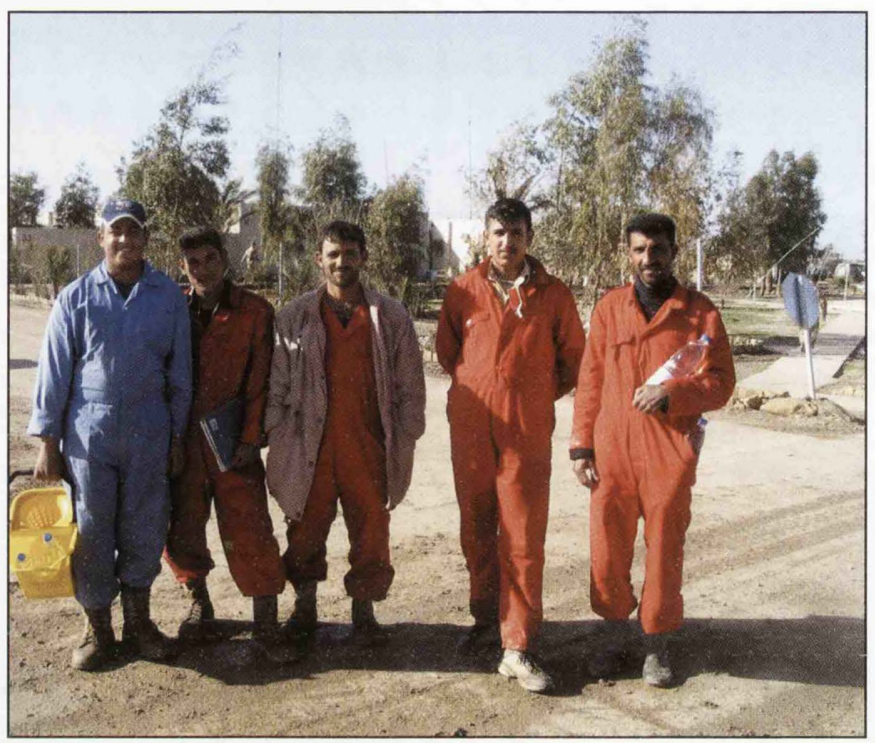

Locally employed Iraqis

After the evening meal, which runs from 1830-1930 hours, I normally spend the rest of the night in the A\&E department, where there may be further patients to see. Due to the immediacy of the IRT I spend the night sleeping partially clothed on a camp bed within the department. On my alternate nights off there is usually a DVD film to watch somewhere in camp or a game of Monopoly or Risk. The sky at night is pitch black and as there is little light pollution the stars are an amazing sight, particularly when it is not raining. At the far end of camp the internet portacabins are co-located with the satellite phones. We are allowed 20 free minutes of calls per week.

\section{CONCLUSION}

I have enjoyed my three-month tour and have made a lot of friends. It has been a very different environment to normal NHS general practice. Clinically, the time has been largely undemanding, but this has been compensated for by experience in trauma and pre-hospital care. I have seen, at first hand, the problems that exist in Iraq, met some of the people and viewed their frustrations. The task is harder than we realise whilst sitting at home watching the TV or reading our newspapers. I sincerely believe that the army is doing a worthwhile job in assisting the locals who are beginning to take control of their own country. It also seems that we shall be in Iraq for some considerable time to come. 